$7-2015$

\title{
Do Size and Value Premia Vary Across Industry and Market Conditions? Evidence from the Euro Area
}

\author{
Maher Asal \\ University West, Sweden \\ Abolhasson Jalilvand \\ Loyola University Chicago, ajalilv@luc.edu \\ Lars Rolseth \\ University West, Sweden
}

Follow this and additional works at: https://ecommons.luc.edu/business_facpubs

Part of the Finance and Financial Management Commons

\section{Recommended Citation}

Asal, Maher; Jalilvand, Abolhasson; and Rolseth, Lars. Do Size and Value Premia Vary Across Industry and Market Conditions? Evidence from the Euro Area. Journal of Business and Policy Research, 10, 1: 96-114, 2015. Retrieved from Loyola eCommons, School of Business: Faculty Publications and Other Works,

This Article is brought to you for free and open access by the Faculty Publications and Other Works by Department at Loyola eCommons. It has been accepted for inclusion in School of Business: Faculty Publications and Other Works by an authorized administrator of Loyola eCommons. For more information, please contact ecommons@luc.edu.

\section{(c) (i) $\ominus$}

This work is licensed under a Creative Commons Attribution-Noncommercial-No Derivative Works 3.0 License. (c) World Business Institute, 2015 


\title{
Do Size and Value Premia Vary Across Industry and Market Conditions? Evidence from the Euro Area
}

\author{
Maher Asal", Abolhassan Jalilvand ${ }^{* *}$ and Lars Rolseth*** \\ This paper investigates whether value and size premia exist in the Euro \\ area's industry returns and, if so, what factors are driving them. We use a \\ Garch-M $(1,1)$ model on daily retum data from the STOXX market indices \\ for five major industries in the euro area. Our findings show that an \\ industry-specific three-factor Fama and French type model does provide a \\ robust explanation of returns over the period, 2001-2012. While, our results \\ further emphasize the widespread influence of the value and size effects in \\ the Euro market, the pattern, sign, size, and significance of these factors \\ vary widely across different industries and market conditions.
}

JEL Codes: C22. C52. G12.

\section{Introduction}

The elimination of the exchange rate risk within the Euro area and the continuing harmonization and integration of monetary and regulatory policy rules among the member states have provided an intriguing opportunity to re-examine the key underlying risk factors that determine security returns in the European equity markets. Such structural changes have also affected portfolio selection rules, risk management strategies, and approaches to cost of capital determination in the Euro area. As the long standing skepticism about the predictions and relevance of the Capital Asset Pricing Model (CAPM) has continued to persist, researchers have focused on alternative empirical models to explain security returns in a global setting (see for example, Stultz and Wasserfallen (1995)). One such extension is the three-factor model proposed by Fama and French (1992, 1993, 1995, 1996, 1998, 2006, and 2012) which underlies the observation that stocks with small market capitalization and those with high book to price (market value) ratios have conventionally yielded higher returns, presumably reflecting their higher systematic risk, than those predicted by the traditional CAPM. The higher returns appear to be related to two additional risk factors capturing size and value characteristics of the sample firms. ${ }^{\text {T }}$ The "value premium" accounts for the difference in returns between high book to market and low book to market ratio portfolios "High minus Low" (HML). The "size premium" accounts for the difference in returns between small and big capitalization portfolios "Small minus Big" (SMB). However, in spite of the overwhelming empirical support, the existence and persistence of these premia have remained a puzzle among researchers and portfolio managers.

In this paper, we focus on some key asset pricing questions in the Euro Area: do value and size premia exist in the Euro Area; are these factors determined by Euro-wide influences or they are industry-specific; are their persistence influenced by different market environments, such as the "bull" and "bear" markets prevailing in the recent past; and

\footnotetext{
Maher Asal, University West, Sweden. Maher.asal@hv.se

"Abolhassan Jalilvand, Loyola University Chicago, USA. ajalilv@luc.edu

"Lars Rolseth, University West, Sweden, lars.rolseth.2@hv.se.
} 
finally, are value and size effects generated by a momentum effect reflecting systematic short-term gains (or losses) relative to the market as a whole. Our contributions to the existing literature are in several fold. First, we apply a GARCH-M $(1,1)$ model to a more recent industry-based return index data from 12 Euro countries over the period 2001-2012. The GARCH-M $(1,1)$ model with non-normal error distribution is a powerful tool in modeling non-linearity of stock returns. By allowing the variance of the error term to change over time, this model is expected to provide more accurate estimates of returns than those obtained by the OLS technique. Second, following Griffin (2002) and Moerman (2005), we use an industry-based approach in examining the Euro Area portfolio returns index, contending that regulatory changes should induce investors to take an industrybased approach in examining the Euro Area portfolio returns. Third, we test the dynamics of value and size effects both during the bull market (2003-2007) and the bear market (2007-2009). Changes in market conditions and investors' perception may alter the potential valuation impact of a firm's market capitalization and its growth opportunities. This distinction will further allow us to examine the momentum effect in Euro security returns. Fourth, we use two measures of value and growth stocks by subdividing the sample into strong value and growth categories representing the top $20 \%$ companies in the Euro Total market Index (TMI). Fifth and finally, using the Euro zone STOXX TMI indices, we use a more comprehensive characterization to select value firms. Specifically, unlike previous studies which have commonly used one or two factors in identifying value firms, we use six factors; namely, projected price/earnings (P/E) ratio, projected earnings growth, trailing $P / E$ ratio, trailing earnings growth, price/book $(P / B)$ ratio, and dividend yield to construct value stocks. To our knowledge, no other paper has considered these factors for the Euro Area. In addition, consistent with standard asset pricing recommendation, we use industry index return rather than firm level return to allow for a significant reduction or elimination of the idiosyncratic risk in the regression analysis.

The paper is organized as follows. Section 2 reviews previous studies. Section 3 presents the model and the econometric methodology applied to industry-based rather than country-based returns. Section 4 provides the empirical results, and section 5 will offer concluding remarks.

\section{Literature Review}

Black (1993) argued that the relationship between stock returns, size and value premium was a result of data mining. A similar notion was advanced by Kothari, Shanken, and Sloan (1995), who contended that the significant book-to-market relation is due to survivorship bias. Using a dynamic risk-based model, Lettau and Wachter (2007) showed that growth firms (long-horizon equity) correlate more with the discount rate than do value firms (short-horizon equity) which correiate more with cash flows. They concluded that value stocks do not appear to be riskier than growth stocks.

Focusing on international data, Fama and French (1998) tested the global version of their model for a number of different world equity markets, concluding that value stocks were associated with higher returns than growth stocks. Other studies provided further support for the significance of size and value premia as well as exchange rate risk for security markets in Australia, Hong Kong, Italy, Japan, Korea, Malaysia, and the Philippines (see, for example, Chan, Hamao, and Lakonishok (1991), Halliwell et al. (1999), Capaul, Rowley, and Sharpe (1993), Murgia et al. (2000), and Drew and Veeraraghavan (2003)). More recently, however, researchers have focused on whether the pricing effects of value 
and size factors are mostly due to country-specific (local) portfolios rather than market wide risk factors suggested by the Fama and French model (1998). Griffin (2002) and Mirza (2011) show that the Fama and French factors are, in fact, country specific for the U.S, the U.K, Canada, and Japan. Building on the work by Griffin (2002), Moerman (2005) tested different versions of the Fama and French three-factor model using both country and industrial data in the Euro Area from 1991-2002. Specifically, he suggested that integration of the European equity markets implies that portfolio returns could be better explained by an industry-specific three-factor model than both the corresponding Eurowide and the country-specific versions. His findings show that the Euro Area three-factor model underperforms the country three-factor model in explaining both country-based and industry-based portfolios. Further, the results show that the relative performance of the Euro Area wide model is increasing, particularly for countries with a high number of listed stocks.

Petkova and Zhang (2005) find that the economic fundamentals of value firms respond negatively and quite forcefully to economic shocks while this is not true for growth stocks. Their results supports the conventional risk-based argument for the higher observed returns on value portfolios, at least in the adverse states of the world. Hahn and Lee (2006) examined whether the size and book-to-market factors of Fama and French (1993) proxy for the risks associated with business cycle fluctuations. They found that changes in default spread and changes in term spread capture the systematic differences in average returns along the size and book-to-market measurements. They concluded that the size and value premiums are compensation for higher exposure to the risks related to changing credit market conditions and interest rates. More recently, Choi (2013) investigates how asset risk and financial leverage explains the equity risk dynamics of value versus growth stocks. During recession, the asset betas and leverage of value firms increase, which lead to a sharp rise in equity betas. On the other hand, asset betas of growth firms are much less sensitive to economic conditions. He shows that the interactions of conditional betas with the market risk premium and volatility explain a large proportion of unconditional value premium. Eraslan (2013) tests the validity of the Fama and French three-factor asset pricing model in the Istanbul Stock Exchange (ISE). He found, for the period 2003 to 2010 , negative size premium (that is large firms outperform small firm returns) and a negative value premium (that is growth stocks outperform value stocks). Negative size premia were also reported by Faff (2004) on Australian daily returns from 19996 to 1999, raising further questions on the robustness of the Fama and French type models for international data.

\section{Econometric Modeling and Data}

\subsection{Data}

We use the daily return data index provided by STOXX indices for the five major industries in the Euro Area: Basic Materials, Consumer Goods, Consumer Services, Financials, and Industrials for the period 2001-2012. The index is updated each 6 month removing dead stocks and including new companies; thus, avoiding sample selection and survivorship bias.

The benchmark used in this paper is the Total Market Index (TMI) Euro index consisting of 595 stocks. The EURO STOXX (TMI) covers approximately 95 percent of the free float market capitalization of Europe and represents a broad coverage of Eurozone companies. 


\section{Asal, Jalilvand \& Rolseth}

The index includes Austria, Belgium, Finland, France, Germany, Greece, Ireland, Italy, Luxembourg, the Netherlands, Portugal, and Spain.

The size premium is defined as Euro small cap minus Euro large cap, while value premium is defined as Euro value stocks minus Euro growth stocks.i The value and growth stocks are further subdivided into strong value and strong growth categories representing the top 20 strongest value and growth stocks in the TMI index, respectively. Consequently, an additional premium was calculated, namely, strong value premium to measure excess return of Euro strong value stocks over Euro strong growth stocks. Moreover, during the sample period, there were two major shifts in the equity return series due to a strong bull market (2003-2007) and a strong bear market characterized by the sub-prime mortgage crisis (2007-2009). We select the lowest and highest returns in the TMI index to define starting and ending points for the bull and the bear markets. Changes in market conditions and investors' perception may alter the potential valuation impact of a firm's market capitalization and its growth opportunities. Jalifvand and Kim (2013) find that under turbulent market environments such as the Dot.Com bubble (1999-2002) and the sub-prime mortgage crisis (2007-2009), some firms tend to use more flexible slack resources to finance growth opportunities and innovation while others attempt to entrench by accumulating cash and liquid assets to create a buffer against the risk of financial distress. They further argue that such decisions may well change the firm's risk profile and investors' perception. The 1-day interbank interest rate for the Euro zone, EONIA, is obtained from the ECB database for the period of analysis. iii

\subsection{The Model}

We start with the three-factor model developed by Fama and French (1992, 1993, 1995, 1996, 1998, 2006 and 2012). Recognizing that an important implication of the European Monetary Union and the resulting highly integrated equity markets is that industry factors may logically become more important relative to country-specific factors, and following Moerman (2005), we apply an industry-based three-factor model to explain security returns in the Euro area. The following time series regression equation is used:

$$
R_{i t}-R_{f t}=\alpha_{i}+\beta_{i M}\left(R_{M t}-R_{f t}\right)+\beta_{i s} S M B_{t}+\beta_{i h} H M L_{t}+\varepsilon_{i t}
$$

Where $R_{i t}-R_{f t}$ is the excess return on the industry index, $R_{f t}$ is the EONIA (The Euro Over Night Index Average) rate of return, $R_{M t}$ is the Return on the TMI index, $S M B_{t}$ is the size premium defined as the difference between returns on small cap and large cap in TMI indices, and $H M L_{t}$ is the value premium defined as the difference between returns of value and growth indices. $\beta$ is the parameter estimate for the risk factors and $\alpha$ forms the timeseries regression estimate used to calibrate how rapidly stock prices respond to new information (see for example, Loughran and Ritter (1995), Mitchell and Stafford (2000)). It is also used to measure either the special propriety information or a particular set of skills portfolio managers may hold (Carhart's (1997) in generating abnormal returns.

Econometrically, we use GARCH-M model of Engle, Lilien, and Robins (1987) to estimate the parameters in equation (1). The GARCH-M approach takes into consideration that stock returns may be influenced by their volatility. The GARCH-M is an extension of the basic GARCH framework which allows the conditional mean return to depend on its conditional variance or standard deviation. The GARCH model is used with Students tdistribution. The GARCH-M $(1,1)$ model can be written as: 


\section{Asal, Jalilvand \& Rolseth}

$$
\begin{aligned}
& x_{t}=u+\lambda \sigma_{t}+a_{t} \\
& \sigma_{t}^{2}=\alpha_{0}+\sum_{i=1}^{p} \alpha_{i} a_{t-i}^{2}+\sum_{j=1}^{q} \beta_{j} \sigma_{t-j}^{2} \\
& a_{t}=\sigma_{t} \times \varepsilon_{t} \\
& \varepsilon_{t} \sim P_{v}(0,1)
\end{aligned}
$$

Where $x_{t}$ is the time series value at time $t, \mu$ is the mean of GARCH model, $\lambda$ is the volatility coefficient (risk premium) for the mean, $a_{t}$ is the model's residual at time $t, \sigma_{t}$ is the conditional standard deviation or volatility at time $t, p$ is the order of the ARCH component model, $\alpha_{i}$ coefficients are the parameters of the ARCH component model, $q$ is the order of the GARCH component model, $\beta_{\mathrm{j}}$ coefficients are the parameters of the GARCH component model. $\varepsilon_{\mathrm{t}}$ is the standardized residual, where $\left[\varepsilon_{\mathrm{t}}\right] \sim$ i.i.d, $E\left[\varepsilon_{\mathrm{t}}\right]=0$, $\operatorname{VAR}\left[\varepsilon_{\mathrm{t}}\right]=1$, and $\mathrm{P}_{v}$ is the probability distribution function for $\varepsilon_{\mathrm{t}}$. Finally, with Student's $t-$ distribution, $\mathrm{P}_{v}=\mathrm{t}_{v}(0,1), v>4$.

\section{Empirical Results}

\subsection{Summary Statistics}

Figures (1) - (3) show the cumulative return trend-lines for the five industries, value and growth as well as small and large cap portfolios vs. the benchmark (TMI) in the Euro Area over the entire period, 2001-2012. As shown in Figure (1), Basic Materials, Consumer Goods and Industrials have achieved higher returns than the TMI index while the reverse has been true for Consumer Services and Financials. The results during the bull market (2003-2007) are different as returns for Basic Materials, Financials and Industrials have been higher than those achieved by Consumer Goods and Consumer Services. The results for the bear market are the same as those for the entire period.

Figure 1: Cumulative Returns by Industry vs. TMI benchmark in the Euro Area: 2001-2012

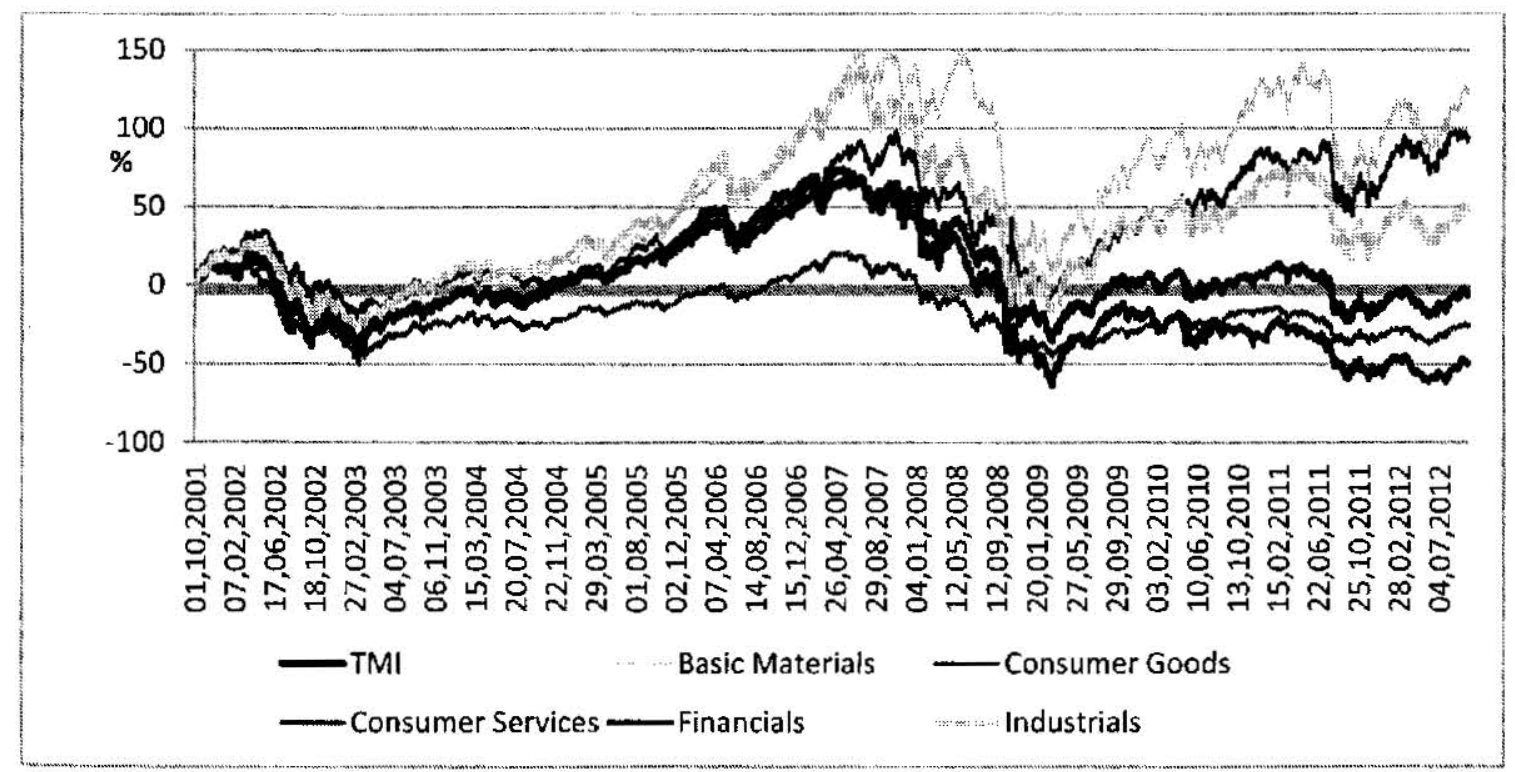




\section{Asal, Jalilvand \& Rolseth}

The results in Figure (2) show that growth portfolios have yielded higher cumulative returns than those of value and benchmark portfolios. These results contradict the previous findings (see, for example, Fama and French (1992) and Arshanapalli et al. (1998)). Further, there are no differences in the pattern of portfolio returns in the bull (2003-2007) or the bear (2007-2009) markets.

Figure 2: Cumulative Returns for Value and Growth Stock Portfolios in the Euro Area: 2001-2012

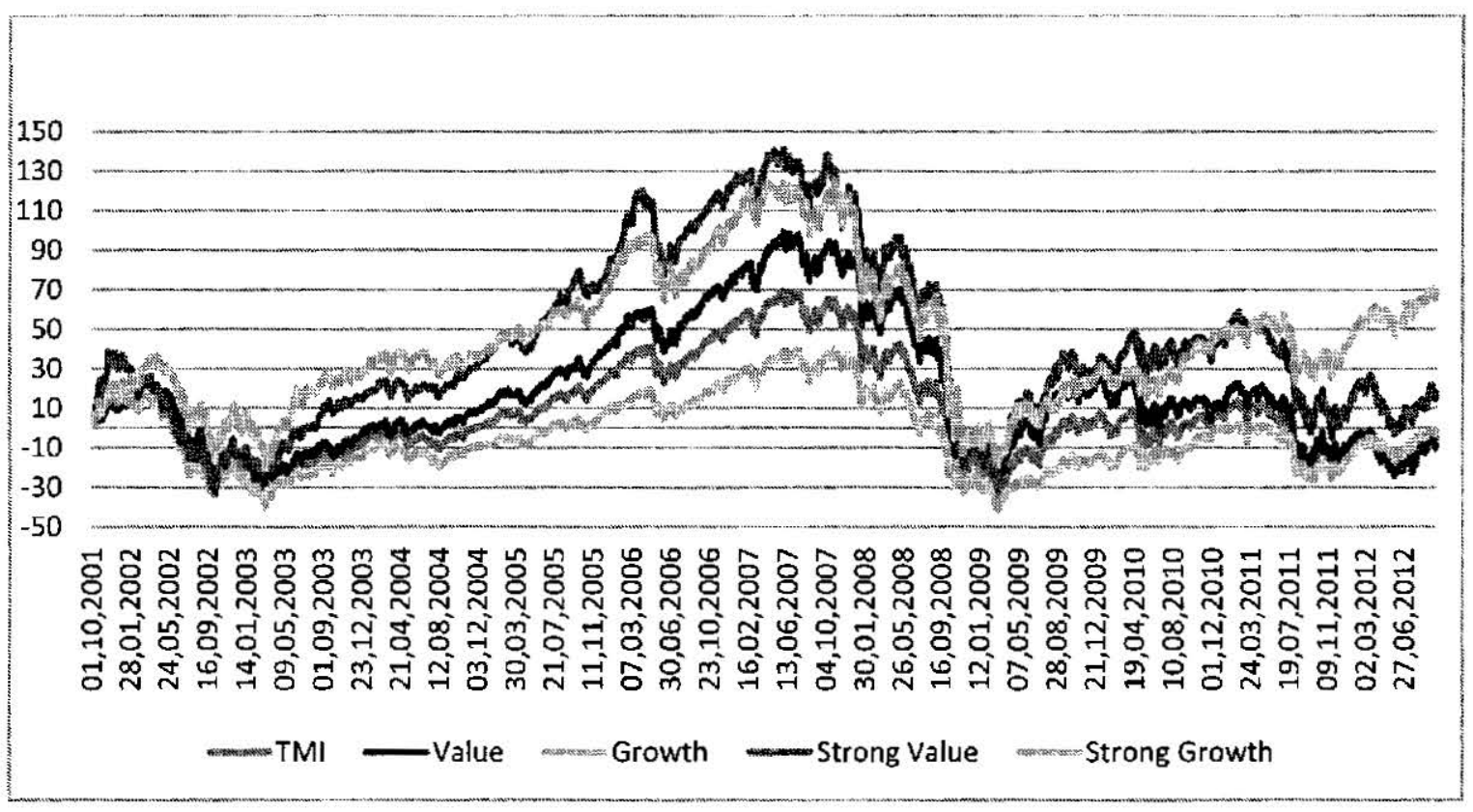

Figure (3) indicates a clear size premium in the Euro industry-based returns which is independent of the bull and the bear market conditions. These results are consistent with the previous findings reported earlier. Our result, however, contradicts the findings of Faff (2004) and Eraslan (2013) who found a negative size premium in Australia and Istanbul, respectively. 
Figure 3: Cumulative Returns of Small and Large Cap in the Euro Area, 2001-10-01 to 2012-10-03

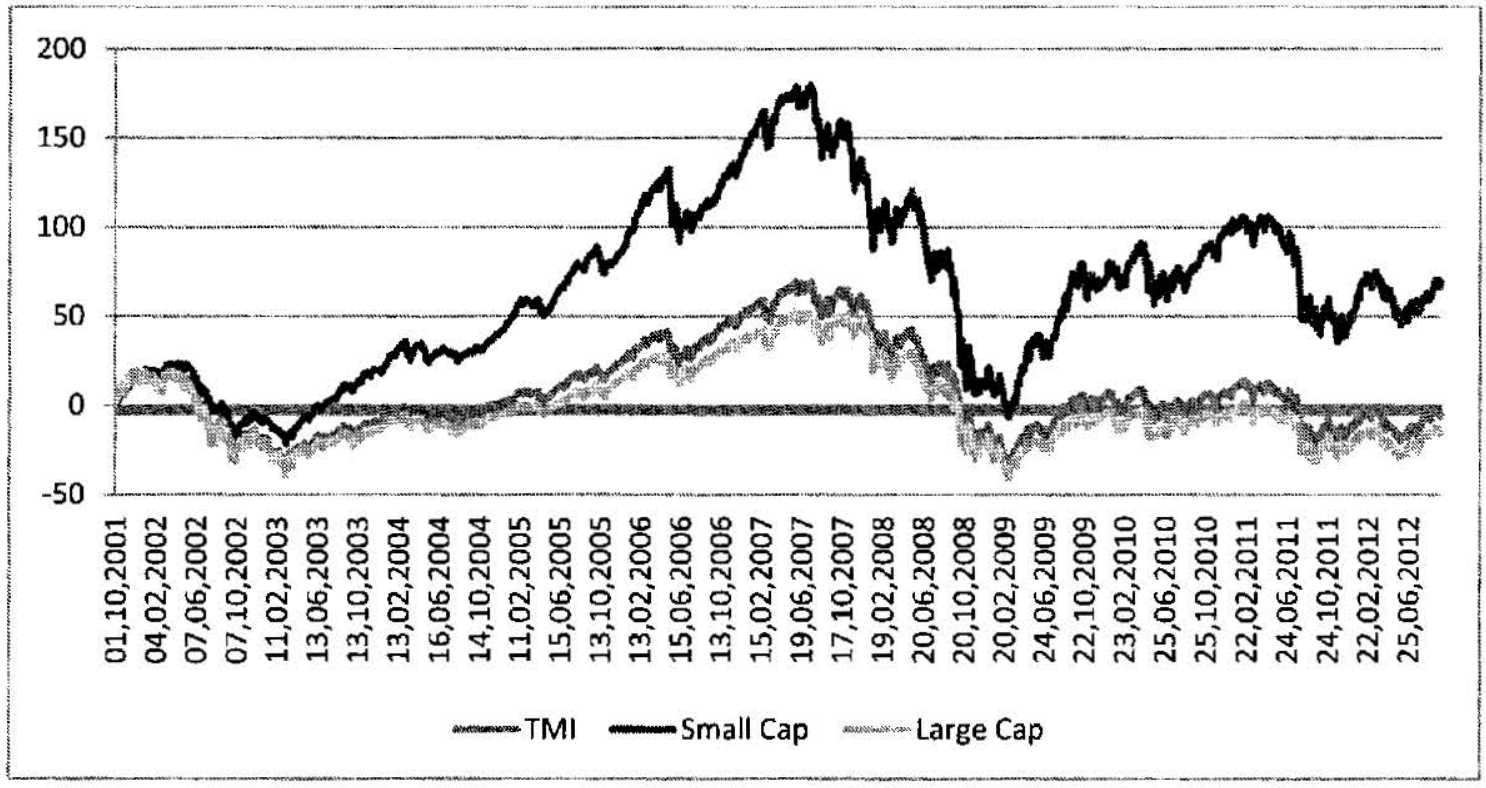

Table (1) provides summary statistics on excess returns and cumulative returns for the five industries, TMI index, value stocks, growth stocks, small cap, and large cap stocks. We have also calculated the mean, standard deviation (a proxy for total risk), rewards-to-risk ratio (RTR), skewness, excess kurtosis, minimum, maximum, and asymptotic test $x^{2}$ for the entire sample period. The data revels that all return series are highly non-normal with high excess kurtosis that could be due to the impact of the bull and bear markets. These observations provide a strong case for using the GARCH approach to take into consideration that stock returns may be influenced by their volatility.

As observed in Figures (1) - (3), the results in table (1) also show that portfolio returns across different industries vary widely over different periods and under different market environments. For the full sample, the cumulative return on the value portfolio was lower than that of the benchmark while the reverse was true for the growth portfolio. Also, for the same period, the small cap portfolio return was significantly higher than that of the large cap portfolio. For the full sample, these result suggest a positive size premium and a negative value premium (i.e. growth stocks yield higher returns than value stocks). Overall, the superior performance of the growth portfolio may reflect the observation that growth firms perform best in the latter stages of the economic cycle (the Great Recession began at the end of 2007). Also growth firms may benefit from a "momentum" effect as the economy strengthens.

On the other hand, the value portfolio yields higher returns than growth, strong growth, large-cap, and blend stock portfolios in the bull market (2003-2007). The small-cap portfolio has generated higher return than the large-cap and blend index in full sample and in the bull market environment while the large-cap portfolio provides higher returns than small-cap and blend index in the bear market (2007-2009). These results hold for strong value and strong growth stocks as well. Overall, they suggest there may be a size premium and a positive value premium (i.e. value stocks outperform growth stocks) in the bull market. However, for the bear market, the results suggest a negative size (i.e. large 


\section{Asal, Jalilvand \& Rolseth}

cap outperform small cap) and a negative value premium (i.e. growth stocks outperform value stocks). iv Further, the momentum effect is not present in all sectors, except in the Basic Materials which has consistently performed better both in the bear and bull markets. These findings provide further support for the main conclusion by Petkova and Zhang (2005) in that value firms respond negatively and quite powerfully to economic shocks while this is not true for growth stocks. This could be interpreted as an indication that value stocks are riskier than growth stocks, at least in the adverse states of the world. Also in Table (1), over the entire period, value stocks have had a higher standard deviation than that of growth stocks. ${ }^{\vee}$ To further include risk in our analysis, we have computed the rewards-to risk ratio using the excess return and the total risk measured by the standard deviation for the full sample and over the entire period. These results are reported in the fourth column of Table (1). The results support the previous finding in that Basic Materials outperform all the other sectors and growth and strong growth stocks outperform the value and strong value portfolios, respectively. In addition, the small cap portfolio outperforms both large cap and the benchmark portfolios during the whole sample period. Further, if the risk-based view of size and value premia is correct, we should also expect beta values for small cap portfolios to be higher than those of the large cap portfolios under different market conditions. This is what we attempt to do next. 


\section{Asal, Jalilvand \& Rolseth}

Table 1: Summary statistics: Industry Excess Returns and TMI Index in the Euro Area: 2001-2012.

TMI = STOXX Euro index consisting of 595 stocks. Basic Materials, Consumer G, Consumer S. Financials, Industrials $=$ industries in the STOXX TMI Euro index. Value $=$ value stocks in the STOXX TMI index, Growth = growth stocks in the STOXX Euro TMI index. Strong Value $=$ the 20 strongest value stocks in the STOXX Euro TMI index. Strong Growth $=$ the 20 strongest growth stocks in the STOXX Euro TMI index. Size Premium = STOXX Euro large cap minus STOXX Euro small cap, Value Premium = STOXX Euro Value minus STOXX Euro Growth, Strong Value Premium = STOXX Euro Strong Value minus STOXX Euro Strong Growth.

\begin{tabular}{|c|c|c|c|c|c|c|c|c|c|}
\hline \multirow[b]{2}{*}{ Indust } & \multicolumn{6}{|c|}{$\begin{array}{l}\text { The first difference log excess return: whole } \\
\text { sample }\end{array}$} & \multicolumn{3}{|c|}{ Return for period } \\
\hline & Mean & Std, & RTR & Skew & $\begin{array}{l}\text { Ex, } \\
\text { Kurt. }\end{array}$ & Norm, $x^{2(2)}$ & $\begin{array}{l}\text { Full } \\
\%\end{array}$ & $\begin{array}{l}\text { Bull } \\
\%\end{array}$ & $\begin{array}{l}\text { Bear } \\
\%\end{array}$ \\
\hline $\begin{array}{l}\text { Basic } \\
\text { Materials }\end{array}$ & .0002 & 0,016 & 0,012 & $-0,09$ & 5,171 & $\begin{array}{l}1206,5 \\
{[0,0000]^{* \star}}\end{array}$ & 122 & 240 & $-57,1$ \\
\hline $\begin{array}{l}\text { Consumer } \\
G\end{array}$ & .0002 & 0,014 & 0,011 & 1,044 & 25,01 & $\begin{array}{l}6675,4 \\
{[0,0000]^{\star *}}\end{array}$ & 94 & 128 & $-52,7$ \\
\hline Consumer S & -.0002 & 0,013 & -0 & $-0,07$ & 4,075 & $00]^{* \star}$ & $-25,3$ & 54 & $-53,3$ \\
\hline Financials & -.0003 & 0,019 & $-0,02$ & 0,223 & 5,476 & $\begin{array}{l}1264,5 \\
{[0,0000]^{\star \star}}\end{array}$ & $-49,5$ & 155 & -77 \\
\hline Industrials & .0001 & 0,015 & 0,003 & $-0,09$ & 5,678 & $50]^{* *}$ & 46,5 & 208 & $-63,9$ \\
\hline Value & -.0001 & 0,016 & $-0,01$ & 0,042 & 5,789 & $\begin{array}{l}1414,5 \\
{[0,0000]^{\star \star}}\end{array}$ & -9 & 167 & -64 \\
\hline Growth & -.0001 & 0,014 & $-0,01$ & 0,006 & 3,777 & $\begin{array}{l}776,59 \\
{[0,0000]^{* *}}\end{array}$ & & 107 & -58 \\
\hline $\begin{array}{l}\text { Strong } \\
\text { Value }\end{array}$ & -.0001 & 0,016 & -0 & $-0,03$ & 5,642 & $\begin{array}{l}1366,3 \\
{[0,0000]^{\star \star}}\end{array}$ & 17,2 & 189 & $-69,6$ \\
\hline $\begin{array}{l}\text { Strong } \\
\text { Growth }\end{array}$ & .0001 & 0,014 & 0,007 & $-0,22$ & 6,714 & $\begin{array}{l}1672,8 \\
{[0,0000]^{* *}}\end{array}$ & 70,1 & 139 & $-62,5$ \\
\hline Small Cap & .0001 & 0,012 & 0,009 & $-0,38$ & 5,085 & $\begin{array}{l}1051,0 \\
{[0,0000]^{\star \star}}\end{array}$ & 69,3 & 234 & $-65,8$ \\
\hline Large Cap & -.0001 & 0,015 & $-0,01$ & 0,04 & 4,373 & $\begin{array}{l}957,66 \\
{[0,0000]^{\star \star}}\end{array}$ & $-15,1$ & 125 & -60 \\
\hline TMI & -.0001 & 0,014 & $-0,01$ & $-0,02$ & 4,415 & & -5 & 142 & $-60,9$ \\
\hline $\begin{array}{l}\text { Value } \\
\text { Premium }\end{array}$ & .0000 & 0,006 & -0 & 0,098 & 54,26 & & & & \\
\hline $\begin{array}{l}\text { Strong } \\
\text { Value } \\
\text { Premium }\end{array}$ & -.0001 & 0,009 & -0 & 0,198 & 3,423 & $\begin{array}{l}644,48 \\
{[0,0000]^{* \star}}\end{array}$ & & & \\
\hline $\begin{array}{l}\text { Size } \\
\text { Premium }\end{array}$ & .0002 & 0,008 & 0,03 & $-0,38$ & 4,386 & $\begin{array}{l}846,08 \\
{[0,0000]^{* *}}\end{array}$ & & & \\
\hline
\end{tabular}

Table (2) reports the estimated beta (systematic risk) using the CAPM for the full sample, bull and bear markets (equations 2-4). For comparison, we used both OLS and GARCH-M $(1,1)$ estimates. As shown in the table, for the whole sample, the bull and the bear markets, the betas for small caps are consistently lower than those for the large caps. 


\section{Asal, Jalilvand \& Rolseth}

These results contradict the risk-based view explanation of the CAPM. On the other hand, consistent with the previous literature, the betas for value portfolios are consistently larger than those for growth ones. The magnitude of the differences is the largest during the bear market condition. However, beta estimates_for value stocks are less sensitive to market conditions than growth stocks. The betas for value stocks are 1.0254 and 1.0256 , in bull and bear, respectively. As for growth stocks, the betas are 1.0135 and 0.93 , for bull and bear respectively. Thus, we concluded that the growth stocks are more sensitive to market conditions. While, it is true that the beta for value firms increases marginally in the Bear market (from 1.0254 to 1.0256), contrary to Choi (2013), the growth stocks show more sensitivity to market conditions.

The size and value premium effects are further examined in the next section using the Fama and French three factor model. 


\section{Asal, Jalilvand \& Rolseth}

Table 2: Estimated Beta Coefficients: Euro Industry Portfolio Returns, 2001-2012

The first entry in each cell refers to the coefficient value and the second entry refers to $p$ value. See footnote below table 1 . Because of non-convergence estimate in two cases we use an OLS estimate combined with GARCH.

\begin{tabular}{|c|c|c|c|c|c|c|}
\hline & & $\begin{array}{l}\text { GARCH- } \\
\text { M }(1,1)\end{array}$ & & & OLS & \\
\hline Beta & $\begin{array}{l}\text { Full } \\
\text { Sample }\end{array}$ & \begin{tabular}{|l} 
Bull \\
$(2003-$ \\
$07)$
\end{tabular} & $\begin{array}{l}\text { Bear } \\
(2007- \\
09)\end{array}$ & $\begin{array}{l}\text { Full } \\
\text { Sample }\end{array}$ & $\begin{array}{l}\text { Bull } \\
(2003- \\
07)\end{array}$ & $\begin{array}{l}\text { Bear } \\
(2007- \\
09)\end{array}$ \\
\hline Basic Materials & $\begin{array}{l}1.025 \\
(0.00)\end{array}$ & $\begin{array}{l}1.0540 \\
(0.00)\end{array}$ & $\begin{array}{l}1.0827 \\
(0.00)\end{array}$ & \begin{tabular}{|l|}
1.005 \\
$(0.00)$ \\
\end{tabular} & $\begin{array}{l}1.0394 \\
(0.00)\end{array}$ & $\begin{array}{l}1.0961 \\
(0.00)\end{array}$ \\
\hline $\begin{array}{l}\text { Consumer } \\
\text { Goods }\end{array}$ & $\begin{array}{l}0.907 \\
\langle 0.00\rangle\end{array}$ & $\begin{array}{l}0.9826 \\
(0.00)\end{array}$ & $\begin{array}{l}0.9015 \\
(0.00)\end{array}$ & $\begin{array}{l}0.834 \\
(0.00) \\
\end{array}$ & $\begin{array}{l}0.9764 \\
(0.00)\end{array}$ & $\begin{array}{l}0.7235 \\
(0.00)\end{array}$ \\
\hline $\begin{array}{l}\text { Consumer } \\
\text { Service }\end{array}$ & $\begin{array}{l}0.805 \\
(0.00)\end{array}$ & No Conv & $\begin{array}{l}0.8123 \\
(0.00)\end{array}$ & $\begin{array}{l}0.829 \\
(0.00)\end{array}$ & $\begin{array}{l}0.9177 \\
(0.00)\end{array}$ & $\begin{array}{l}0.7901 \\
(0.00)\end{array}$ \\
\hline Financials & $\begin{array}{l}1.1388 \\
(0.00)\end{array}$ & $\begin{array}{l}1.0734 \\
(0.00) \\
\end{array}$ & $\begin{array}{l}1.2324 \\
(0.00)\end{array}$ & $\begin{array}{l}1.262 \\
(0.00)\end{array}$ & $\begin{array}{l}1.0838 \\
(0.00)\end{array}$ & $\begin{array}{l}1.2595 \\
(0.00)\end{array}$ \\
\hline Industrials & $\begin{array}{l}1.029 \\
(0.00)\end{array}$ & $\begin{array}{l}0.9878 \\
(0.00)\end{array}$ & $\begin{array}{l}1.1770 \\
(0.00)\end{array}$ & $\begin{array}{l}0.986 \\
(0.00)\end{array}$ & $\begin{array}{l}0.9392 \\
(0.00)\end{array}$ & $\begin{array}{l}1.1383 \\
(0.00)\end{array}$ \\
\hline Value & $\begin{array}{l}1.037 \\
(0.00)\end{array}$ & $\begin{array}{l}1.0254 \\
(0.00)\end{array}$ & $\begin{array}{l}1.0256 \\
(0.00)\end{array}$ & $\begin{array}{l}1.062 \\
(0.00)\end{array}$ & $\begin{array}{l}1.0246 \\
(0.00)\end{array}$ & $\begin{array}{l}1.1015 \\
(0.00)\end{array}$ \\
\hline Growth & $\begin{array}{l}0.986 \\
(0.00)\end{array}$ & $\begin{array}{l}1.0135 \\
(0.00)\end{array}$ & $\begin{array}{l}0.9369 \\
(0.00)\end{array}$ & $\begin{array}{l}0.9388 \\
(0.00)\end{array}$ & $\begin{array}{l}1.0141 \\
(0.00)\end{array}$ & $\begin{array}{l}0.8971 \\
(0.00)\end{array}$ \\
\hline Strong Value & $\begin{array}{l}0.954 \\
(0.00)\end{array}$ & $\begin{array}{l}0.7964 \\
(0.00)\end{array}$ & $\begin{array}{l}1.0882 \\
(0.00)\end{array}$ & $\begin{array}{l}1.022 \\
(0.00)\end{array}$ & $\begin{array}{l}0.7856 \\
(0.00)\end{array}$ & $\begin{array}{l}1.1445 \\
(0.00)\end{array}$ \\
\hline Strong Growth & $\begin{array}{l}0.836 \\
(0.00)\end{array}$ & $\begin{array}{l}0.8829 \\
(0.00)\end{array}$ & $\begin{array}{l}1.0174 \\
(0.00)\end{array}$ & $\begin{array}{l}0.875 \\
(0.00)\end{array}$ & $\begin{array}{l}0.8820 \\
(0.00)\end{array}$ & $\begin{array}{l}0.8971 \\
(0.00)\end{array}$ \\
\hline Small cap & $\begin{array}{l}0.749 \\
0.00)\end{array}$ & $\begin{array}{l}0.6337 \\
(0.00)\end{array}$ & $\begin{array}{l}0.8751 \\
(0.00)\end{array}$ & $\begin{array}{l}0.738 \\
(0.00)\end{array}$ & $\begin{array}{l}0.6438 \\
(0.00)\end{array}$ & $\begin{array}{l}0.8415 \\
(0.00)\end{array}$ \\
\hline Large Cap & $\begin{array}{l}1.046 \\
(0.00)\end{array}$ & $\begin{array}{l}1.0680 \\
(0.00)\end{array}$ & $\begin{array}{l}1.0131 \\
(0.00)\end{array}$ & $\begin{array}{l}1.049 \\
(0.00)\end{array}$ & $\begin{array}{l}1.0646 \\
(0.00)\end{array}$ & $\begin{array}{l}1.0253 \\
(0.00)\end{array}$ \\
\hline Value Premium & $\begin{array}{l}0.056 \\
(0.00)\end{array}$ & $\begin{array}{l}0.0154 \\
(0.16)\end{array}$ & $\begin{array}{l}0.0942 \\
(0.00)\end{array}$ & $\begin{array}{l}0.123 \\
(0.00)\end{array}$ & $\begin{array}{l}0.0105 \\
(0.00)\end{array}$ & $\begin{array}{l}0.2043 \\
(0.00)\end{array}$ \\
\hline Strong Value $P$. & $\begin{array}{l}0.099 \\
(0.00)\end{array}$ & $\begin{array}{l}-0.1034 \\
(0.00)\end{array}$ & $\begin{array}{l}0.0511 \\
(0.00)\end{array}$ & $\begin{array}{l}0.147 \\
(0.00)\end{array}$ & $\begin{array}{l}-0.096 \\
(0.00)\end{array}$ & $\begin{array}{l}0.1164 \\
(0.00)\end{array}$ \\
\hline Size Premium & $\begin{array}{l}-0.297 \\
(0.00)\end{array}$ & $\begin{array}{l}-0.1034 \\
(0.00)\end{array}$ & $\begin{array}{l}-0.138 \\
(0.00)\end{array}$ & $\begin{array}{l}-0.31 \\
(0.00)\end{array}$ & $\begin{array}{l}-0.420 \\
(0.00)\end{array}$ & $\begin{array}{l}-0.183 \\
(0.00)\end{array}$ \\
\hline
\end{tabular}

\subsection{GARCH Results}

Applying the GARCH-M $(1,1)$ estimation approach to the Fama and French three-factor model should provide information on three different, but related fronts. First, it shows whether the value and size effects are significant (and have the expected sign) across different industries in the Euro area. Second, it verifies whether there are untapped opportunities to generate excess return by analyzing the coefficient for the intercept. If the intercept is significant and different from zero, there are potential to earn excess return as there may still exists other unaccounted risk factors which are not included in the model. Finally, the GARCH-M $(1,1)$ will shed light on whether the historic volatility or risk factor is 


\section{Asal, Jalilvand \& Rolseth}

significant for determining portfolio returns in the Euro area. The historic volatility around the mean returns is labeled as $\sigma^{2}$ in the tables (3) $-(6)$.

Further, the models are evaluated using HMSE and AIC measures. HMSE (Heteroscedasticity-Adjusted Mean Square Error) is a loss function with lower values signifying a model's robustness for forecasting volatility. The Akaike Information Criteria (AIC) is a measure of the relative goodness of fit of a statistical model. A lower AIC value is better in terms of lowering the model's information loss. We also test the possibility that the model is IGARCH and report $(a 1+b 1)$. If $(a 1+b 1)$ is equal to one the model is IGARCH.

Table (3) reports the GARCH-M $(1,1)$ results using both definitions of value and growth stocks for the full sample period. The results suggest that in most cases the second (strong) definition of value and growth is slightly better in terms of AIC and HMSE criteria. Focusing on the top panel of table (4), we notice that the estimates for the coefficient $\alpha_{i}$ are close to zero and insignificant for all sectors. The insignificance of the coefficients $\alpha_{i}$ tends to support the robustness of the Fama and French three-factor model. Second, there is a positive and significant size effect for all sectors, except for the consumer goods. The size effect is strongest for Industrials with a coefficient of $(0.452)$. While the value premium is significant and negative for Consumer Goods, Consumer Service and Industrials, its coefficient is significant and positive for the Financials, and insignificant for the Basic Materials. In sum, for the whole sample and over the entire period, both the size and value premiums seem to be important factors (with different signs) in determining the industry returns in the Euro area. We continue to analyze if these results holds for the bull (2003-2007) and bear (2007-2009) markets using the same methodology. 


\section{Asal, Jalilvand \& Rolseth}

Table 3: GARCH-M (1,1) Results: Full Sample, 2001-2012

Bench $=$ Excess return between STOXX Euro TMI index and EONIA, SMB $=$ STOXX Euro large cap minus STOXX Euro small cap, HML = STOXX Euro Value minus STOXX Euro Growth, SHML = STOXX Euro Strong Value minus STOXX Euro Strong Growth.

\begin{tabular}{|c|c|c|c|c|c|c|c|c|c|c|c|}
\hline \multirow[b]{2}{*}{ Panel I } & Const. & Bench & SMB & $\mathrm{HML}$ & $\mathrm{aO}$ & a1 & b1 & $\sigma$ & & & \\
\hline & Co. & Co. & Co. & Co. & Co. & Co. & Co. & Co. & HMSE & AIC & $a 1+b 1$ \\
\hline \multirow{2}{*}{$\begin{array}{l}\text { Basic } \\
\text { Materials }\end{array}$} & 0.004 & 1.074 & 0.21 & $\overline{0} .001$ & 0.0001 & 0.032 & 0.963 & -0.02 & 6.83 & -7.4 & 0.99 \\
\hline & 0.22 & 0.00 & 0.00 & 0.98 & 0.17 & 0.01 & 0.00 & 0.64 & & & \\
\hline \multirow{2}{*}{$\begin{array}{l}\text { Consumer } \\
\text { Goods }\end{array}$} & 0.003 & 0.942 & 0.02 & $-0,4$ & 0.0001 & 0.102 & 0.874 & -0.03 & 506 & 80 & 007 \\
\hline & 0.26 & 0.00 & 0.07 & 0.00 & 0.00 & 0.00 & 0.00 & 0.60 & 0.00 & -0.0 & \\
\hline \multirow{2}{*}{$\begin{array}{l}\text { Consumer } \\
\text { Service }\end{array}$} & -0.003 & 0.860 & 0.09 & $\overline{0} .240$ & 0.0001 & 0.042 & 0.951 & 0.039 & 5.47 & -8.2 & 0.99 \\
\hline & 0.23 & 0.00 & 0.00 & 0.00 & 0.02 & 0.00 & 0.00 & 0.54 & & & \\
\hline \multirow{2}{*}{ Financials } & -0.002 & 1.154 & 0.03 & 0.539 & 0.0001 & 0.074 & 0.924 & -0.01 & 4.37 & -8.2 & 0.99 \\
\hline & 0.17 & 0.00 & 0.01 & 0.00 & 0.03 & 0.00 & 0.00 & 0.81 & & & \\
\hline \multirow{2}{*}{ Industrials } & -0.003 & 1.148 & 0.45 & $\overline{0} .099$ & 0.0001 & 0.045 & 0.951 & 0.076 & 3.77 & -8.3 & 0.99 \\
\hline & 0.17 & 0.00 & 0.00 & 0.00 & 0.05 & 0.00 & 0.00 & 0.20 & & & \\
\hline \multicolumn{12}{|l|}{ Panel II } \\
\hline \multirow{2}{*}{$\begin{array}{l}\text { Strong } \\
\text { Value and } \\
\text { Growth }\end{array}$} & Con. & Bench. & SMB & SHML & aO & a1 & b1 & $\sigma$ & & & \\
\hline & Co. & Co. & Co. & Co. & Co. & Co. & Co. & Co. & HMSE & $\mathrm{AlC}$ & $a 1+b 1$ \\
\hline \multirow{2}{*}{$\begin{array}{l}\text { Basic } \\
\text { Materials }\end{array}$} & 0.005 & 1.074 & 0.21 & $-0,04$ & 0.0001 & 0.031 & 0.964 & -0.03 & 6.88 & -7.4 & 0.99 \\
\hline & 0.19 & 0.00 & 0.00 & 0.01 & 0.14 & 0.00 & 0.00 & 0.58 & & & \\
\hline \multirow[t]{2}{*}{$\begin{array}{l}\text { Consumer } \\
\text { Goods }\end{array}$} & 0.003 & 0.925 & 0.03 & $\overline{0.113}$ & 0.0001 & 0.106 & 0.873 & -0.03 & 4.57 & -7.9 & 0.98 \\
\hline & 0.21 & 0.00 & 0.02 & 0.00 & 0.01 & 0.00 & 0.00 & 0.49 & & & \\
\hline \multirow{2}{*}{$\begin{array}{l}\text { Consumer } \\
\text { Service }\end{array}$} & -0.002 & 0.842 & 0.11 & $\overline{0.071}$ & 0.0001 & 0.051 & 0.942 & 0.03 & 4.62 & -8.1 & 0.99 \\
\hline & 0.29 & 0.00 & 0.00 & 0.00 & 0.03 & 0.00 & 0.00 & 0.63 & & & \\
\hline \multirow{2}{*}{ Financials } & -0.001 & 1.153 & 0.04 & 0.124 & 0.0001 & 0.075 & 0.925 & -0.02 & 3.95 & -7.9 & 0.99 \\
\hline & 0.66 & 0.00 & 0.01 & 0.00 & 0.06 & 0.00 & 0.00 & 0.49 & & & \\
\hline \multirow{2}{*}{ Industrials } & -0.002 & 1.142 & 0.46 & $\overline{0} .034$ & 0.0001 & 0.045 & 0.951 & 0.069 & 3.64 & -8.3 & 0.99 \\
\hline & 0.21 & 0.00 & 0.00 & 0.00 & 0.06 & 0.00 & 0.00 & 0.24 & & & \\
\hline
\end{tabular}

Focusing on the bull market, top panel of Table (4), the results show that the estimated coefficients ai are also close to zero and insignificant for all sectors. Furthermore, the size premium is significant in three sectors; Basic Materials, Consumer Service and Industrials. The results also show that the value premium is significant in all sectors. However, the coefficients are significantly lower than those for the full sample period. Regarding the 


\section{Asal, Jalilvand \& Rolseth}

bear market, the results in Table (5) also show that the estimated coefficients ai are close to zero and insignificant. The coefficient of size premium is positive and significant for four industries: Basic Material, Consumer Services, Financials, and Industrials. For the value premium, the coefficients are significant and positive for Basic Material and Financials, and negative and significant for the rest of the industries.

Table 4: GARCH M (1,1) Results: Bull Period, 2003-2007

Bench = Excess return between STOXX Euro TMI index and EONIA, SMB $=$ STOXX Euro large cap minus STOXX Euro small cap, HML = STOXX Euro Value minus STOXX Euro Growth, SHML = STOXX Euro Strong Value minus STOXX Euro Strong Growth

\begin{tabular}{|c|c|c|c|c|c|c|c|c|c|c|c|}
\hline \multirow[t]{2}{*}{ Panel I } & Const. & Bench & SMB & $\mathrm{HML}$ & $\mathrm{aO}$ & a1 & $\mathrm{b} 1$ & $\sigma$ & & & \\
\hline & Co. & Co. & Co. & Co. & Co. & Co. & Co. & Co. & HMSE & $\mathrm{AIC}$ & $a 1+b 1$ \\
\hline \multirow{2}{*}{$\begin{array}{l}\text { Basic } \\
\text { Materials }\end{array}$} & 0.003 & 1.126 & 0.192 & 0.247 & 0.001 & 0.215 & 0.172 & $\overline{1} 06$ & 13.73 & -7.9 & 0.39 \\
\hline & 0.78 & 0.00 & 0.00 & 0.00 & 0.00 & 0.03 & 0.44 & 0.80 & & & \\
\hline \multirow{2}{*}{$\begin{array}{l}\text { Consumer } \\
\text { Goods }\end{array}$} & -0.00 & 0.994 & -0.01 & -0.079 & 0.001 & 0.059 & 0.902 & 0.06 & 405 & -86 & 096 \\
\hline & 0.75 & 0.00 & 0.76 & 0.04 & 0.20 & 0.04 & 0.00 & 0.83 & & & \\
\hline \multirow{2}{*}{$\begin{array}{l}\text { Consumer } \\
\text { service }\end{array}$} & -0.01 & 0.901 & 0.099 & -0.207 & 0.001 & 0.045 & 0.935 & 0.30 & 2.96 & -8.6 & 0.98 \\
\hline & 0.17 & 0.00 & 0.00 & 0.00 & 0.22 & 0.05 & 0.00 & 0.36 & & & \\
\hline \multirow{2}{*}{ Financials } & 0.002 & 1.062 & -0.01 & 0.345 & 0.001 & 0.041 & -0.04 & $\overline{0} 83$ & 8.67 & -9.4 & 0.99 \\
\hline & 0.72 & 0.00 & 0.65 & 0.00 & 0.00 & 0.03 & 0.00 & 0.39 & & & \\
\hline Industrials & $\begin{array}{l}-0.001 \\
0.77\end{array}$ & $\begin{array}{l}1.141 \\
0.00\end{array}$ & $\begin{array}{l}0.413 \\
0.00\end{array}$ & $\begin{array}{l}-0.096 \\
0.01\end{array}$ & $\begin{array}{l}00001 \\
0.19\end{array}$ & $\begin{array}{l}0.035 \\
0.00\end{array}$ & $\begin{array}{l}0.957 \\
0.00\end{array}$ & $\begin{array}{l}0.03 \\
0.87\end{array}$ & 4.21 & -8.9 & 0.99 \\
\hline & & & & & & & & & & & \\
\hline \multirow{2}{*}{$\begin{array}{l}\text { Panel II } \\
\text { Strong } \\
\text { Value and } \\
\text { Growth }\end{array}$} & Con. & Bench. & SMB & SHML & $a 0$ & a1 & b1 & $\sigma$ & & & \\
\hline & Co. & Co. & Co. & Co. & Co. & Co. & Co. & Co. & HMSE & $\mathrm{AIC}$ & $a 1+b 1$ \\
\hline \multirow{2}{*}{$\begin{array}{l}\text { Basic } \\
\text { Materials }\end{array}$} & 0.005 & 1.124 & 0.191 & -0.003 & 0.001 & 0.008 & 0.986 & -1.10 & 17.41 & -7.9 & 0.99 \\
\hline & 0.00 & 0.00 & 0.00 & 0.91 & 0.00 & 0.75 & 0.00 & 0.00 & & & \\
\hline \multirow[t]{2}{*}{$\begin{array}{l}\text { Consumer } \\
\text { Goods }\end{array}$} & -0.002 & 0.992 & -.004 & -0.031 & 0.001 & 0.057 & 0.904 & 0.03 & 3.87 & -8.5 & 0.96 \\
\hline & 0.84 & 0.00 & 0.88 & 0.12 & 0.20 & 0.04 & 0.00 & 0.93 & & & \\
\hline \multirow{2}{*}{$\begin{array}{l}\text { Consumer } \\
\text { Service }\end{array}$} & -0.008 & 0.895 & 0.111 & -0.024 & 0.0001 & 0.056 & 0.921 & 0.2 & 2.51 & -8.6 & 0.98 \\
\hline & 0.21 & 0.00 & 0.00 & 0.23 & 0.16 & 0.01 & 0.00 & 0.41 & & & \\
\hline \multirow{2}{*}{ Financials } & 0.003 & 1.055 & -0.01 & 0.031 & 0.0001 & 0.029 & 0.959 & $\overline{0} .14$ & 5.06 & -9.2 & 0.99 \\
\hline & 0.49 & 0.00 & 0.52 & 0.02 & 0.16 & 0.02 & 0.00 & 0.43 & & & \\
\hline Industrials & \begin{tabular}{|l|}
-0.001 \\
0.81
\end{tabular} & $\begin{array}{l}1.139 \\
0.00\end{array}$ & $\begin{array}{l}0.415 \\
0.00\end{array}$ & \begin{tabular}{|l|}
-0.024 \\
0.13
\end{tabular} & $\begin{array}{l}0.0001 \\
0.18\end{array}$ & $\begin{array}{l}0.039 \\
0.00\end{array}$ & $\begin{array}{l}0.952 \\
0.00\end{array}$ & $\begin{array}{l}0.01 \\
0.95\end{array}$ & 3.97 & -3.9 & 0.99 \\
\hline
\end{tabular}




\section{Asal, Jalilvand \& Rolseth}

Table (5): GARCH M (1,1) Results: Bear Period, 2007-2009

Bench $=$ Excess return between STOXX Euro TMI index and EONIA, SMB = STOXX Euro large cap minus STOXX Euro small cap, HML = STOXX Euro Value minus STOXX Euro Growth, SHML = STOXX Euro Strong Value minus STOXX Euro Strong Growth.

\begin{tabular}{|c|c|c|c|c|c|c|c|c|c|c|c|}
\hline \multirow{2}{*}{ Panle A } & Const. & Bench & SMB & HML & $\mathrm{aO}$ & a1 & b1 & $\sigma$ & & & \\
\hline & Co. & Co. & Co. & Co. & Co. & Co. & Co. & Co. & HMSE & $\mathrm{AlC}$ & $a 1+b 1$ \\
\hline $\begin{array}{l}\text { Basic } \\
\text { Materials }\end{array}$ & $\begin{array}{l}0.0017 \\
0.24 \\
\end{array}$ & \begin{tabular}{|l|}
1.080 \\
0.00 \\
\end{tabular} & \begin{tabular}{|l|}
0.221 \\
0.00 \\
\end{tabular} & $\begin{array}{l}0.267 \\
0.01 \\
\end{array}$ & $\begin{array}{l}0.0001 \\
0.46 \\
\end{array}$ & \begin{tabular}{|l|}
0.078 \\
0.01 \\
\end{tabular} & \begin{tabular}{|l|}
0.918 \\
0.00 \\
\end{tabular} & \begin{tabular}{|l|}
-0.07 \\
0.64 \\
\end{tabular} & 2.73 & -6.6 & 0.99 \\
\hline $\begin{array}{l}\text { Consumer } \\
\text { Goods }\end{array}$ & $\begin{array}{l}-0.001 \\
0.76 \\
\end{array}$ & $\begin{array}{l}0.91 \\
0.00 \\
\end{array}$ & $\begin{array}{l}-0.06 \\
0.27\end{array}$ & $\begin{array}{l}0.607 \\
0.00\end{array}$ & $\begin{array}{l}0.0001 \\
0.00\end{array}$ & $\begin{array}{l}0.547 \\
0.00 \\
\end{array}$ & $\begin{array}{l}-0.01 \\
0.89 \\
\end{array}$ & \begin{tabular}{|l|}
0.086 \\
0.87 \\
\end{tabular} & 46.37 & -7.1 & 0.54 \\
\hline $\begin{array}{l}\text { Consumer } \\
\text { Service }\end{array}$ & $\begin{array}{l}-0.001 \\
0.03 \\
\end{array}$ & \begin{tabular}{|l|}
0.874 \\
0.00 \\
\end{tabular} & $\begin{array}{l}0.239 \\
0.00 \\
\end{array}$ & $\begin{array}{l}- \\
0.145 \\
0.00\end{array}$ & $\begin{array}{l}0.0001 \\
0.22 \\
\end{array}$ & $\begin{array}{l}0.134 \\
0.01 \\
\end{array}$ & $\begin{array}{l}0.866 \\
0.00 \\
\end{array}$ & $\begin{array}{l}0.199 \\
0.22 \\
\end{array}$ & 3.56 & -7.5 & 0.99 \\
\hline Financials & $\begin{array}{l}0.0001 \\
0.98\end{array}$ & \begin{tabular}{|l|}
1.199 \\
0.00 \\
\end{tabular} & \begin{tabular}{|l|}
0.101 \\
0.05 \\
\end{tabular} & \begin{tabular}{|l|}
0.546 \\
0.00 \\
\end{tabular} & $\begin{array}{l}0.0001 \\
0.09 \\
\end{array}$ & \begin{tabular}{|l|}
0.148 \\
0.01 \\
\end{tabular} & \begin{tabular}{|l|}
0.852 \\
0.00 \\
\end{tabular} & \begin{tabular}{|l|}
-0.09 \\
0.38 \\
\end{tabular} & 3.66 & -7.0 & 0.99 \\
\hline Industrials & $\begin{array}{l}-0.001 \\
0.26 \\
\end{array}$ & $\begin{array}{l}1.23 \\
0.00 \\
\end{array}$ & $\begin{array}{l}0.397 \\
0.00\end{array}$ & \begin{tabular}{|l}
- \\
0.348 \\
0.00
\end{tabular} & $\begin{array}{l}0.0001 \\
0.16 \\
\end{array}$ & $\begin{array}{l}0.178 \\
0.11 \\
\end{array}$ & $\begin{array}{l}0.772 \\
0.00 \\
\end{array}$ & $\begin{array}{l}0.225 \\
0.28 \\
\end{array}$ & 4.40 & -7.5 & 0.95 \\
\hline \multirow[t]{2}{*}{$\begin{array}{l}\text { Panel B } \\
\text { Strong } \\
\text { Value and } \\
\text { growth }\end{array}$} & Const. & Bench & SMB & SHML & $\mathrm{aO}$ & a1 & b1 & $\sigma$ & & & \\
\hline & Co. & Co. & Co. & Co. & Co. & Co. & Co. & Co. & HMSE & AIC & $a 1+b 1$ \\
\hline $\begin{array}{l}\text { Basic } \\
\text { Materials }\end{array}$ & $\begin{array}{l}0.002 \\
0.21\end{array}$ & $\begin{array}{l}1.092 \\
0.00\end{array}$ & $\begin{array}{l}0.149 \\
0.04\end{array}$ & $\begin{array}{l}- \\
0.014 \\
0.75\end{array}$ & $\begin{array}{l}0.0001 \\
0.30\end{array}$ & $\begin{array}{l}0.091 \\
0.00\end{array}$ & $\begin{array}{l}0.901 \\
0.00\end{array}$ & $\begin{array}{l}-0.01 \\
0.54\end{array}$ & 2.85 & -6.5 & 0.99 \\
\hline $\begin{array}{l}\text { Consumer } \\
\text { Goods }\end{array}$ & $\begin{array}{l}0.0003 \\
0.68 \\
\end{array}$ & $\begin{array}{l}0.907 \\
0.00 \\
\end{array}$ & \begin{tabular}{|l|l|}
0.090 \\
0.13 \\
\end{tabular} & $\begin{array}{l} \\
0.060 \\
0.10 \\
\end{array}$ & $\begin{array}{l}0.0001 \\
0.34 \\
\end{array}$ & $\begin{array}{l}0.373 \\
0.06 \\
\end{array}$ & $\begin{array}{l}0.596 \\
0.01 \\
\end{array}$ & \begin{tabular}{|l|}
-0.05 \\
0.63 \\
\end{tabular} & 35.73 & -7.0 & 0.96 \\
\hline $\begin{array}{l}\text { Consumer } \\
\text { Service }\end{array}$ & $\begin{array}{l} \\
0.0013 \\
0.02 \\
\end{array}$ & $\begin{array}{l}0.865 \\
0.00 \\
\end{array}$ & $\begin{array}{l}0.279 \\
0.00 \\
\end{array}$ & \begin{tabular}{|l|l|}
0.025 \\
0.42 \\
\end{tabular} & $\begin{array}{l}0.0001 \\
0.20 \\
\end{array}$ & \begin{tabular}{|l|}
0.130 \\
0.10 \\
\end{tabular} & $\begin{array}{l}0.870 \\
0.00 \\
\end{array}$ & $\begin{array}{l}0.234 \\
0.16 \\
\end{array}$ & 3.73 & -7.5 & 0.99 \\
\hline Financials & $\begin{array}{l}0.0001 \\
0.96 \\
\end{array}$ & \begin{tabular}{|l|}
1.232 \\
0.00 \\
\end{tabular} & \begin{tabular}{|l|}
0.111 \\
0.04 \\
\end{tabular} & \begin{tabular}{|l|}
0.354 \\
0.00 \\
\end{tabular} & $\begin{array}{l}0.0001 \\
0.06\end{array}$ & \begin{tabular}{|l|}
0.181 \\
0.12 \\
\end{tabular} & \begin{tabular}{|l|}
0.819 \\
0.00 \\
\end{tabular} & $\begin{array}{l}-0.08 \\
0.43 \\
\end{array}$ & 5.88 & -7.1 & 0.99 \\
\hline Industrials & $\begin{array}{l}- \\
0.0012 \\
0.15\end{array}$ & $\begin{array}{l}1.217 \\
0.00 \\
\end{array}$ & $\begin{array}{l}0.431 \\
0.00\end{array}$ & $\begin{array}{l}- \\
0.090 \\
0.00\end{array}$ & $\begin{array}{l}0.0001 \\
0.15\end{array}$ & $\begin{array}{l}0.316 \\
0.09\end{array}$ & $\begin{array}{l}0.593 \\
0.01 \\
\end{array}$ & $\begin{array}{l}0.278 \\
0.20 \\
\end{array}$ & 4.15 & -7.4 & 0.91 \\
\hline
\end{tabular}

As we mentioned at the outset of this paper, we focused on several key asset pricing questions in the Euro Area: is an industry-specific model of security return appropriate for the Euro area; do value and size premiums exist in the Euro Area; are their persistence influenced by different market environments, such as the "bull" and "bear" markets prevailing in the recent past; and, finally, are value and size effects generated by a momentum effect. Our results offer important insights on the above queries.

1. Our findings show that an industry-specific three-factor Fama and French type model provides a robust explanation of security returns in the European equity markets over the period 2001-2012. The model's intercept coefficients ( $a$ ) are 


\section{Asal, Jalilvand \& Rolseth}

insignificant under varying samples, different market conditions, and across different industries. Our results provide additional support for Moerman's (2005) contention that an industry-specific three-factor model performs well in explaining the European equity returns.

2. We provide further support on the widespread influence of the "value" and "size" premia in the Euro market. However, the pattern, sign, size, and significance of these factors vary widely across different industries and market conditions.

a. The size premium predominantly plays a positive, stable and significant role in explaining security returns for all industries and during the "bull" (20032007) and "bear" (2007-2009) markets.

b. The result for the value premium is mixed. The value premium effect is positive and significant in industries such as Basic Materials and Financials and negative and relatively insignificant for Consumer Goods, Consumer Services, and Industrials.

3. We found value stocks to be generally associated with higher beta than those of growth stocks. Further, the overall magnitude of the value premium effect is relatively larger in the bear market than in the bull market. This observation provide additional support for Petkova and Zhang (2005) and Choi (2013) who contend that the economic fundamentals of value firms respond negatively and quite forcefully to economic shocks while this may not be true for growth stocks.

4. Finally, the momentum effect is only present in the Basic Materials industry which has consistently performed better than others under all market conditions.

\section{Conclusions}

During the last decade, the elimination of exchange rate risk and overall integration of the European equity markets have created new opportunities for using industry-specific diversification and portfolio strategies. Our findings show that an industry-specific threefactor Fama and French type model provides a robust explanation of security returns in the European equity markets over the period 2001-2012. The model's intercept coefficients $(\alpha)$ are insignificant under varying samples, different market conditions, and across different industries. While, we provide further support on the widespread influence of the "value" and "size" premiums in the Euro market, the pattern, sign, size, and significance of these factors vary widely across different industries and market conditions. The size premium predominantly plays a positive, stable and significant role in explaining security returns. On the other hand, the results for the value premium is mixed. The estimated coefficient of the value premium was found to be negative and significant in over 60 percent of the cases examined in this study.

Nor does our results provide convincing evidence in support of the risk-based view for the existence of size and value premium effects. For the whole sample, the bull and the bear markets, the betas for small caps are consistently lower than those for the large caps. Further, while the betas for value portfolios are larger than those for growth ones, the magnitude of the differences are the largest only during the bear market condition. Our findings is consistent with those of Petkova and Zhang (2005) and Choi (2013) in that value firms respond negatively and quite powerfully to economic shocks while this is not 


\section{Asal, Jalilvand \& Rolseth}

true for growth stocks. However, our results differ from those of Faff (2004) and Eraslan (2013) who found a negative size premium in Australia and Istanbul, respectively. We see two specific areas for future extension of the present paper. First, we may sort betas on the basis of expected market risk premium instead of realized rate of return. And, second, rate of return may be constructed based on individual companies rather than market index portfolios.

\section{Endnotes}

1. For US empirical evidence, see, for example, Bans (1981), Bhandari (1988), Lakonishok, Shleifer and Vishny (1994), and Fama and French (1992, 1993, 1995, and 1997)).

2. See table 1 for more detailed explanation on how SMB and HML are measured.

3. Daily data has some advantageous over monthly data. First, financial data are observed without measurement error. Second, the assumptions underlying portfolio return over a specified interval are more severely violated with monthly returns and that monthly return intervals provide less timely feedback for managers. On the other hand, daily return suffers from too much noise and that daily stock returns depart more from normality than monthly returns do (Fama (1976)), but this is mitigated in this paper by using the GARCH model

4. The mixed result in different states of the economy on the relation between value and growth portfolios might also be explained by the difficulty in timing the market. Since the full sample period is very volatile, the market has been difficult to time. Further, most portfolio managers today evaluate their portfolios to style risk. Investment opportunities due to style might disappear due to transmission effects.

5. Conventionally, growth stocks represent companies that are currently thriving, while value stocks commonly represent companies in trouble; hence, the price of the former may be higher than the price of the latter. Since investors attempt to avoid risk in falling markets, they are prepared to pay extra for quality shares and invest in growth shares. In a bull market, investors are prepared to take a higher risk and to invest in value shares.

\section{References}

Arshanapalli, BT, Coggan, D \& Doulas, J 1998,'Multifactor Asset Pricing Analysis of International Value Investment Strategies', Journal of Portfolio Management, vol. 24, no. 4., pp. 10-23.

Bans, R 1981, 'The Relationship Between Return and Market Value of Common Stocks', Journal of Financial Economics, vol. 9, pp. 3-18

Bhandari, LC 1988, 'Debt/Equity Ratio and Expected Common Stock Returns: Empirical Evidence', Journal of Finance, vol. 43, pp. 507-528.

Black, F1993, 'Estimating expected return', Financial Analysts Journal, vol. 49, no. 5, pp. 36-38.

Capaul, C, Rowley, I \& Sharpe, W1993, 'International value and growth stock returns', Financial Analysts Journal, vol. 49, pp. 27-36.

Carhart, M 1997, 'On Persistence in Mutual Fund Performance', Journal of Finance vol. 52 , no. 1, pp. 57-82.

Chan, K, Hamao, Y, \& Lakonishok, J 1991, 'Fundamentals and Stock Returns in Japan', Journal of Finance, vol. 46, pp. 1739 - 1764.

Chan, K, Jegadeesh, N \& Lakonishok, J 1996, 'Momentum Strategies', Journal of Finance, vol. 51, no. 5 pp. 1681-1713.

Chan, K, Karceski, J, and Lakonishok, J 2000, 'New Paradigm or Same Old Hype in Equity Investing?', Financial Analysts Journal, pp. 23-36.

Chan, K \& Lakonishok, J 2004, 'Value and Growth Investing: Review and Update'. Financial Analysts Journal, vol. 60, no. 1 pp. 71-86. 


\section{Asal, Jalilvand \& Rolseth}

Choi, J 2013, 'What Drives the Value Premium?: The Role of Asset Risk and Leverage', The Review of Financial Studies, vol. 26, no. 11, pp. 2845-2875.

Drew, M E, \& Veeraraghavan, M 2003, 'A closer look at the size and value premium in emerging markets: Evidence from the Kuala Lumpur Stock Exchange', Asian Economic Journal, vol. 16, pp. 337-351.

Engel, R F, Lilien, D M \& Robins, R P 1987, 'Estimating Time Varying Risk Premia in the Term Structure: The Arch-M Model', Econometrica, vol. 55, pp. 391-407.

Eraslana, V 2013, 'Fama and French Three-Factor Model: Evidence from Istanbul Stock Exchange', Business and Economics Research Journal', vol. 4, no. 2, pp. 11-22.

Faff, R 2004, 'A simple test of the Fama and French model using daily data: Australian evidence', Applied Financial Economics, vol. 14, no. 2, pp. 83-92.

Fama, E F 1976, The Foundation of Finance, New York Basic Books.

Fama, E F, \& French, KR 1992, 'The Cross Section of Expected Stock Returns', Journal of Finance, vol. 47, pp. 427-465.

Fama, E F, \& French, KR 1993, 'Common Risk Factors in the Returns on Stocks and Bonds', Journal of Financial Economics, vol. 33. pp. 3-56.

Fama, EF, \& French, KR 1995, 'Size and Book-to-Market Factors in Earnings and Returns', Journal of Finance, vol. 50, pp. 131-155.

Fama, EF, \& French, KR 1996, 'Multifactor Explanations of Asset Pricing Anomalies', Journal of Finance, vol. 51, pp. 55-84.

Fama, EF, \& French, KR 1998, 'Value versus Growth: The International Evidence', Journal of Finance, vol. 53, pp. 1975-1999.

Fama, EF., \& French, KR 2006, 'Dissecting Anomalies', Working Paper, Graduate School of Business, University of Chicago.

Fama, EF, \& French, KR 2012, 'Size, Value, and Momentum in International Stock Returns', Journal of Financial Economics, vol. 105, no.3, pp. 457-72.

Griffin, JM, 2002, 'Are the Fama and French Factors Global or Country Specific?', Review of Financial Studies, vol. 15, pp. 783-803.

Griffin, JM \& Karoly, GA 1998, 'Another look at the role of the industrial structure of markets for international diversification strategies', Journal of Financial Economics, vol. 50. pp. 351-373.

Hahn, J, Lee, H 2006, 'Yield spreads as alternative risk factors for size and book-tomarket', Journal of Financial and Quantitative Analysis, vol.41, no.2, pp. 245-269.

Halliwell, J, Heaney, J \& Sawicki, J 1999, 'Size and book to market effects in Australian share markets: a time series analysis', Accounting Research Journal, vol. 12. pp. 122-137.

Jalilvand, A, and Kim, SM, 2013, "Matching slack resources and Investment strategies to achieve long-term performance: new perspectives on corporate adaptability', Journal of Economic Asymmetries, vol. 10, no. 1, pp. 38-52.

Kothari, S, Shanken, J, \& Sloan, R, 1995, 'Another look at the cross-section of expected stock returns', The Journal of Finance, vol. L, no. 1. pp. 185-225.

Lakonishok,J, Shleifer, A \& Vishny, RW 1994, 'Contrarian Investment, Extrapolation and Risk', Journal of Finance, vol. 49, pp.1541-1578.

Lettau, M \& Wachter, J 2007, 'Why is long-horizon equity less risky? A Duration-based explanation of the value premium', Journal of Finance, vol. 56, no 1., pp. 55-92

Loughran, T \& Ritter, J 1995 'The New Issues Puzzle', Journal of Finance, vol. 50, no. 1, pp. 23-51.

Mitchell, ML \& Staford, E 2000, 'Managerial decisions and long-term stock price performance', Journal of Business, vol.73, pp. 287-329. 


\section{Asal, Jalilvand \& Rolseth}

Mirza, N \& Mahmud, M 2011, 'Evaluating mutual fund performance in an emerging Asian economy: The Malaysian experience', Journal of Asian Economics, vol. 21, pp. 378390.

Murgia, M, Aleati, A, \& Gottardo, P, 2000, 'The pricing of Italian Equity Returns', Economic Notes, vol. 29, no. 2, pp. 153-177.

Moerman, GA 2005, 'How Domestic is the Fama and French Three-Factor Model? An application to the Euro Area', ERIM Report Series Reference, No. ERS-2005-035F\&A, pp. 1-32.

Petkova, R \& Zhang, L 2005, 'Is value riskier than growth?', Journal of Financial Economics, vol. 78, pp. 187-202.

Stulz, RM, Wasserfallen, W, 1995, 'Foreign equity investment restrictions, capital flight and shareholder wealth maximization: Theory and evidence', Review of Financial Studies, vol. 8, pp. 1019-1105. 